\title{
Analysis of Factors Affecting Consumer Intention in Buying Goods on Social Media (Case Study: XYZ Shop)
}

I Gede Adhiarta Wiandana ${ }^{1}$, Erma Suryani ${ }^{2}$

${ }^{1}$ Departement of Technology Management, Institut Teknologi Sepuluh Nopember, Surabaya, Indonesia.

${ }^{2}$ Departement of Information Systems, Institut Teknologi Sepuluh Nopember, Surabaya, Indonesia. e-mail:adhiarta.wiandana@gmail.com

\begin{abstract}
The number of internet users worldwide has increased from year to year. Especially in Indonesia, in 2017 internet users have reached 143.26 million people or around $54.68 \%$ of the total population in Indonesia and on average use it every day. The growth of internet use in Indonesia was used by business people to run their business by selling where social media is the most used place to sell $(64.9 \%)$. However, there are still many consumers who are reluctant to make the intention to purchases, this is caused by many factors including the level of consumer confidence, consumer risk perceptions, and others. In this study, the factors that influence consumer behavior will be analyzed about intention purchasing decisions on social media using the developed Theory of Planned Behavior. The case study used is the XYZ store that sells shoes, accessories, and goods on social media. Partial Least Square Method of Structural Equation Modeling (PLSSEM) is used to analyze the research, where the results of this study are to get the conclusions of significant factors that influence consumer intention to purchases product on social media and recommendations for improvements to XYZ stores to improve sales and get more consumers.
\end{abstract}

Keywords-Theory of Planned Behavior, Consumer Behavior, Purchasing Decisions, Partial Least Square, Structural Equation Model.

\section{INTRODUCTION}

$\mathrm{T}$ HE number of internet users around the world including in Indonesia has increased from year to year. In 2017, internet users in Indonesia reached 143.26 million people or around $54.68 \%$ of the total population in Indonesia and on average use them every day [1]. This shows that most of Indonesia's population cannot be separated from activities that use the internet, such as searching for news information, e-mail, social media, and shopping for necessities. With the phenomenon of the growing use of the internet in Indonesia, of course it is widely used by business people to run their businesses. By using the internet, buyers and sellers can save costs, effort, and no longer need to waste time meeting in person by simply accessing online shops using the internet anytime and anywhere through smart devices. Based on a survey conducted by APJII, the most widely used platforms for selling online on the internet are social media (64.9\%), messenger (22.9\%), online community (14.4\%) [2]. According to the survey, Facebook (50.7\%) and Instagram (17.8\%) are the most visited social media in Indonesia [3]. This shows that social media is a tool that is widely used by business people to sell goods and services.

$\mathrm{XYZ}$ store is one of the shops that uses social media Facebook and Instagram as a place to sell their products such as clothes, shoes, accessories for women and others. However, there is a problem where the number of buyers who purchase goods at this XYZ shop does not increase. Many shoppers are simply wondering about prices and product information without making a purchase at the store.

Although there are many places selling online on social media, there are as many as $56 \%$ of internet users in Indonesia who say they have never shopped via the internet [3]. This is due to several factors, among others, buyers prefer to buy directly because they immediately get the goods $(18.8 \%)$, worry that the goods will not arrive $(9.5 \%)$, worry that the goods are not suitable $(9 \%)$ [3]. This is reinforced by the results of a survey, where $45.14 \%$ of internet users only look for price comparisons of goods sold on the internet [2]. In addition, the number of fraud cases committed by sellers when selling goods in online stores is one of the reasons for the lack of buyers to shop online. In the period January 2018 - December 2019 there were 3398 cases of online fraud, where the fraud cases on social media Instagram (535 cases) and Facebook (304 cases) were in the top 3 .

The behavior of prospective buyers who use the internet to shop is still very diverse. Some easily make purchases without much thought and some are very careful in the buying process. A decision to make a purchase is a complex one and takes place through a very long process. There are two factors that influence the desire to buy, namely those caused by other people's attitudes such as other people's reviews of the goods we are going to buy and factors that cannot be controlled such as economic crises, natural disasters and others. To reduce the impacts caused by these factors, the buyer tends to limit how much risk they can face. According to Kotler and Keller, buyers tend to maximize the value of goods within the limitations of search, knowledge, mobility and income. Buyers tend to choose sellers who provide complete product information. This will affect the number of purchases of goods at the seller [4].

This study aims to analyze what factors can influence the desire of potential buyers to buy products on social media. Where in the future these influencing factors can be used to increase the number and loyalty of buyers. In this study, the authors took a case study of the XYZ store where the XYZ shop is an online shop that sells Muslim shoes, bags and clothing.

Theory of Planned Behavior

Theory of Planned Behavior (TPB) is a development of Theory of Reasoned Action (TRA) which is based on the limitations of the original model in handling the behavior / actions of a person who has no control over his will (Ajzen, 


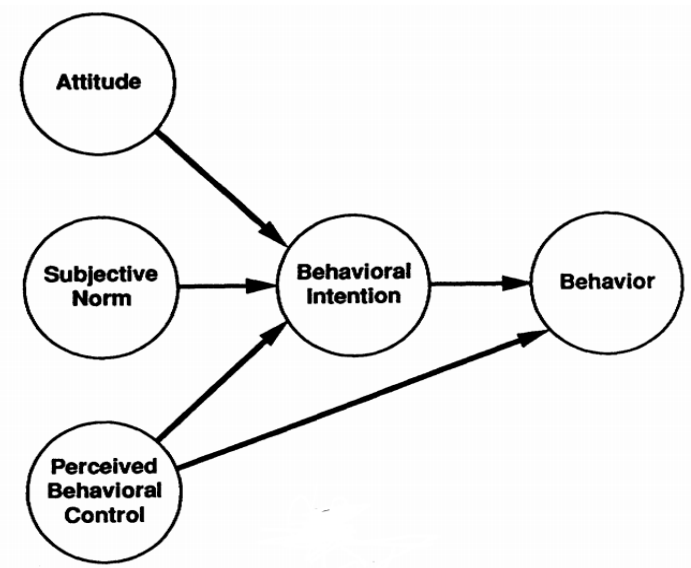

Figure 1. Model of Theory of Planned Behavior

1991). In TRA, the intention (intention) of a person's behavior is influenced by attitudes and subjective norms. Attitudes (attitudes) refer to the extent to which a person can make an assessment / evaluation of a behavior. Meanwhile, subjective norms refer to the extent to which a person is able to accept social pressure on the behavior they do. Behavioral Intention is an indication of how strong a person is to try, how much effort a person puts into a behavior.

The model of TPB is shown in Figure 1 where TPB adds perceived behavior control as an influence on behavior intentions and behaviors that will be carried out by a person. Perception of behavioral control refers to a person's perception of whether or not it is easy to perform a behavior that is considered attractive. In TPB, a person's behavior is influenced by the desire to do (intention) and perceptions of behavior control.

Research Model

The TPB model is widely used as a basic literature to understand the factors that influence online purchasing behavior. Such as research conducted by Assyifa on the factors that influence the desire and purchase of organic food [5]. Andi about the factors that influence purchasing decisions at online stores [6] and many others.

Even so, the researchers added several other factors to support the TPB model in understanding customer shopping behavior at online stores on social media. According to Ajzen [7] the stronger the desire to do an action, the greater the action will occur. This also affects the desire of buyers to buy products on social media. In this study, there are several factors that influence the desire of buyers to buy products on social media such as buyer attitudes, subjective norms, risk perceptions, levels of trust, perceptions of behavior control and satisfaction with the information obtained.

H0: There are no factors that influence a buyer 's intention to make purchases on social media.

H1: The intention of a buyer to make purchases on social media is influenced by several factors.

H2: The attitude of potential buyers has a direct effect on the intention to buy products on social media

H3: Subjective Norms for shopping on social media have a direct effect on the intention to shop on social media.

H4: Perceived behavior control has a direct effect on the intention of buyers to shop on social media.

According to Park, information satisfaction affects the desire of buyers to buy goods. This information is in the form

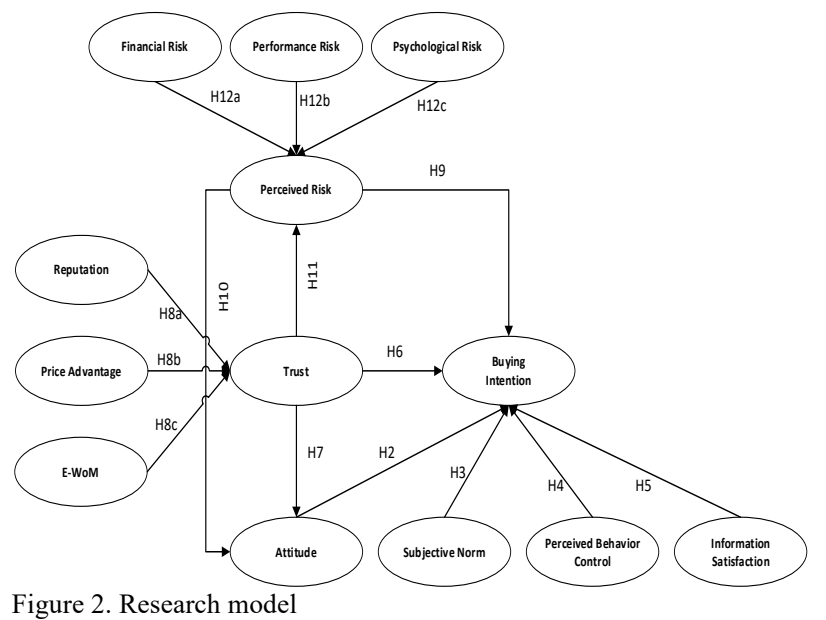

of an explanation of the product being sold, the ordering process and others [8].

H5: Information satisfaction has a direct effect on the intention of buyers to shop on social media.

As research conducted by Imene Ben Yahia [9] states that trust has a direct and positive effect on the desire of a prospective buyer to make a purchase. In shopping on social media, buyer's trust is the buyer's level of confidence in the seller to provide products or services in accordance with the agreed agreement. Trust is a very important factor in the buying and selling process on social media or in conventional stores

H6: Buyer trust has a direct effect on the intention of buyers to shop on social media.

H7: The trust of buyers has a direct effect on the attitudes of buyers to shop on social media.

The trust of a prospective buyer is influenced by the price advantage and reputation of the shop owned by the seller. [9]. In addition to price and reputation advantages, EWoM also affects the level of buyer's trust in the shop [10].

H8a: A seller's reputation has a direct effect on the trust of buyers to shop on social media.

H8b: Price advantage has a direct effect on buyer trust to shop on social media.

H8c: E-WoM has a direct effect on shoppers' trust to shop on social media.

Perceived Risk has a negative effect on Buying Intention, where the greater the perceived risk that the buyer will accept, the smaller the desire to make a purchase [11]. In shopping on social media, risk perception is the possible loss that potential buyers get from shopping online. For example, the product does not match the image, lost / damaged items during delivery, and others [6]. Buyers 'trust in sellers can reduce buyers' perceptions of risk from opportunistic behavior owned by sellers [12].

H9: Buyers perceived risk have a direct effect on buyers' intention to purchase goods on social media.

H10: Perceived risk has a direct and negative effect on the attitudes of buyers to shop on social media.

H11: Trust has a direct and negative effect on perceived risk of buyers towards shopping on social media.

Potential buyers' risk perceptions on social media are influenced by financial risk, performance risk, and psychological risk that will be faced [13]. 
H12a: Financial risk has a direct effect on the perceived risk of buyers to shop on social media.

H12b: Performance risk has a direct effect on buyers' perceived risk for shopping on social media.

H12c: Psychological risk has a direct effect on the perceived risk of buyers to shop on social media.

The research model shown in Figure 2 comes from the Theory of Planned Behavior by adding several factors from previous studies, buying intention is influenced by several factors including Perceived Risk, Trust, Attitude, Subjective Norm, Perceivede Behavior Control, and Information Satisfaction. Then for Trust is influenced by several factors including Reputation, Price Advantage, and E-WoM. Perceived Risk is influenced by several factors including Financial Risk, Performance Risk, and Psychological Risk. And finally, Attitude is influenced by several factors including Trust and Perceived Risk.

\section{METHOD}

Data collecting method using digital questionnaire from Google Form. The structure of the questionnaire questions consists of multiple choice questions, dichotomous questions and questions using a Likert scale.

The population of this study are people who frequently access social media, especially social media Facebook and Instagram. The number of respondents obtained after distributing questionnaires from 14 June 2019 - 28 June 2019 were 366 respondents. It is necessary to check the results of the questionnaire to determine whether the results of the questionnaire are feasible or not. After examining the questionnaire, there were 4 questionnaires that were declared inadequate because they filled out the questionnaire with inappropriate answers (4 respondents). So that the remaining 362 questionnaires will be analyzed further.

Analysis that use in this research descriptive analysis and PLS-SEM analysis. After doing the descriptive analysis, then proceed with the PLS-SEM analysis. The PLS-SEM analysis step is Evaluation of the Measurement Model, consists of Validity Test and Reliability Test. The validity test consists Loading factor indicator test used to evaluate the model is or between $0.4-0.7$ or greater than 0.7 , Average variance extracted value greater than 0.5 , Discriminant validity and cross loading. Reliability test consists of testing the composite reliability indicator value greater than 0.7 and Cronbach's alpha value greater than 0.7. Structural Mode Estimation, tested using the R-Square value and the path coefficient. Hypothesis testing, measured by the p-value of each path coefficient. The $p$-value is below 0.05 , the hypothesis is accepted, while if it is above 0.05, the hypothesis is rejected

\section{RESULT AND DISCUSSION}

\section{A. Analysis}

The descriptive analysis contained in this study consists of Respondent Gender, age, domicile, occupation, monthly income, and access to social media within 1 day. Table 1 shown result of descriptive analysis in this research.

Among the 36 indicators in this study, there are 3 indicators, namely PA03, PR01, and REP01 which have
Table 1.

Descriptive Analysis

\begin{tabular}{|c|c|c|}
\hline & Frequency & Percentage \\
\hline \multicolumn{3}{|c|}{ Gender } \\
\hline Male & 236 & $35 \%$ \\
\hline Female & 126 & $65 \%$ \\
\hline \multicolumn{3}{|c|}{ Age } \\
\hline$<20$ Years Old & 121 & $33 \%$ \\
\hline 20 - 30 Years Old & 228 & $63 \%$ \\
\hline$>30$ Years Old & 13 & $4 \%$ \\
\hline \multicolumn{3}{|c|}{ Domicile } \\
\hline Java Island & 276 & $76 \%$ \\
\hline Outside Java Island & 86 & $24 \%$ \\
\hline \multicolumn{3}{|c|}{ Occupation } \\
\hline Student & 166 & $46 \%$ \\
\hline Private Employees & 102 & $28 \%$ \\
\hline Entrepreneur & 23 & $7 \%$ \\
\hline Government Employees & 12 & $3 \%$ \\
\hline Other & 58 & $16 \%$ \\
\hline \multicolumn{3}{|c|}{ Monthly Income } \\
\hline$<$ Rp. 2.000 .000 & 162 & $45 \%$ \\
\hline Rp. 2.000 .000 - Rp 5.000.000 & 103 & $28 \%$ \\
\hline RP. 5.000.000 - Rp 10.000.000 & 72 & $20 \%$ \\
\hline > Rp. 10.000 .000 & 25 & $7 \%$ \\
\hline \multicolumn{3}{|c|}{ Access To Social Media Within 1 Day } \\
\hline$<3$ Hours & 54 & $15 \%$ \\
\hline 3 - 5 Hours & 169 & $47 \%$ \\
\hline$>5$ Hours & 139 & $38 \%$ \\
\hline
\end{tabular}

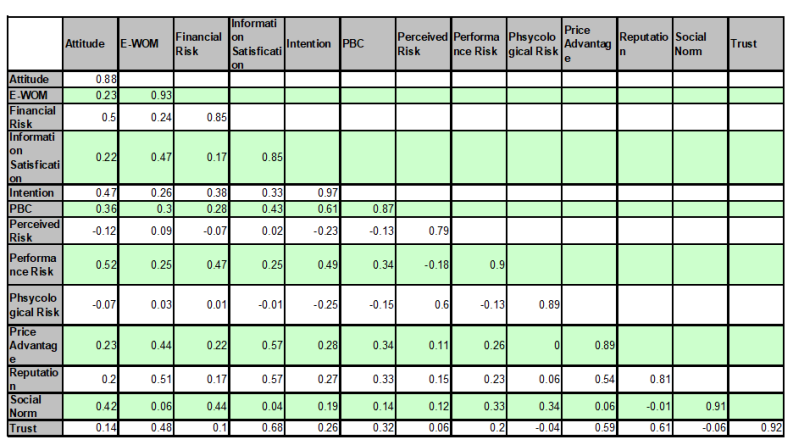

Figure 3. Discriminant Variety Result

values below 0.7 , but have values between $0.4-0.7$. If there is an indicator that has a value of $0.4-0.7$, it is removed if it increases the AVE and Composite Reliability values so that they pass the threshold. After checking, the PA03 indicator has the best results, namely increasing the AVE value, Composite Reliability and Cronbach's Alpha, so that the PA03 indicator will be eliminated. Table 2 shows all indicators are declared valid because they have met the criteria for the Loading Factor parameter. 
The $2^{\text {nd }}$ International Conference on Global Development - ICODEV

December $5^{\text {th }}$, 2020, Online Conference

Table 2.

Loading Factor Result

\begin{tabular}{lccc}
\hline \hline Indicator & $\begin{array}{c}\text { Loading } \\
\text { Factor }\end{array}$ & Indicator & $\begin{array}{c}\text { Loading } \\
\text { Factor }\end{array}$ \\
\cline { 2 - 2 } ATT01 & 0.89 & PBC02 & 0.822 \\
ATT02 & 0.873 & PER01 & 0.910 \\
EWOM01 & 0.908 & PER02 & 0.888 \\
EWOM02 & 0.947 & PHY01 & 0.841 \\
EWOM03 & 0.922 & PHY02 & 0.902 \\
FR01 & 0.756 & PHY03 & 0.921 \\
FR02 & 0.823 & PR01 & 0.684 \\
FR03 & 0.947 & PR02 & 0.826 \\
INF01 & 0.869 & PR03 & 0.843 \\
INF02 & 0.886 & REP01 & 0.641 \\
INF03 & 0.885 & REP02 & 0.875 \\
INF04 & 0.735 & REP03 & 0.890 \\
INT01 & 0.972 & SOS01 & 0.973 \\
INT02 & 0.970 & TROS02 & 0.976 \\
PA01 & 0.837 & & 0.760 \\
PA02 & 0.879 & & 0.927 \\
PBC01 & & TRUS03 & 0.943 \\
\hline \hline
\end{tabular}

Table 3.

AVE Result

\begin{tabular}{ccc}
\hline \hline Variable & AVE Value & Status \\
\hline Intention & 0.943 & Valid \\
Perceived Risk & 0.621 & Valid \\
Trust & 0.847 & Valid \\
Attitude & 0.776 & Valid \\
Social Norm & 0.825 & Valid \\
Pbc & 0.763 & Valid \\
Information Satisfaction & 0.716 & Valid \\
Reputation & 0.656 & Valid \\
Price Advantage & 0.789 & Valid \\
E-Wom & 0.858 & Valid \\
Performance Risk & 0.808 & Valid \\
Phsycological Risk & 0.79 & Valid \\
Financial Risk & 0.715 & Valid \\
\hline \hline
\end{tabular}

AVE is used to measure the convergence level of validity. Is a measure used to explain the indicator variance of a latent variable. The AVE value is declared valid if it exceeds 0.5 . Table 3 shows that all latent variables have an AVE value above 0.5 so that all latent variables are declared valid.

Validity discrimination is used to measure the extent to which a construct differs from other constructs, in addition it
Table 4.

Composite Reliability Result

\begin{tabular}{ccl}
\hline \hline Variable & $\begin{array}{c}\text { Composite } \\
\text { Reliability value }\end{array}$ & Status \\
\hline Intention & 0.874 & Reliable \\
Perceived Risk & 0.948 & Reliable \\
Trust & 0.882 & Reliable \\
Attitude & 0.909 & Reliable \\
Social Norm & 0.971 & Reliable \\
PBC & 0.865 & Reliable \\
Information & 0.830 & Reliable \\
Satisfaction & 0.894 & Reliable \\
Reputation & 0.918 & Reliable \\
Price Advantage & 0.882 & Reliable \\
E-WoM & 0.849 & Reliable \\
Performance Risk & 0.933 & Reliable \\
Psychological Risk & 0.943 & Reliable \\
Financial Risk & &
\end{tabular}

Table 5.

Cronbach Alpha Result

\begin{tabular}{ccl}
\hline \hline Variabel & $\begin{array}{c}\text { Cronbach' Alpha } \\
\text { Value }\end{array}$ & Status \\
\hline Intention & 0.712 & Reliable \\
Perceived Risk & 0.917 & Reliable \\
Trust & 0.838 & Reliable \\
Attitude & 0.867 & Reliable \\
Social Norm & 0.939 & Reliable \\
PBC & 0.700 & Reliable \\
Information & 0.706 & Reliable \\
Satisfaction & 0.764 & Reliable \\
Reputation & 0.866 & Reliable \\
Price Advantage & 0.734 & Reliable \\
E-WoM & 0.736 & Reliable \\
Performance Risk & 0.906 & Reliable \\
Phsycological Risk & 0.910 & Reliable \\
Financial Risk & &
\end{tabular}

is also used to measure the correlation between constructs and measure the number of indicators that represent one construct. The validity discrimination value is declared valid if the square root value of the AVE must be greater than the correlation value between latent variables. Figure 3 indicates that all latent variables meet the criteria, so that all latent variables are declared valid.

Cross loading is a correlation indicator with different constructs in the model. The cross loading value is declared valid if the loading factor value of each indicator against its latent variable has a higher loading value than the loading indicator value for other variables. Figure 4 indicates that all 


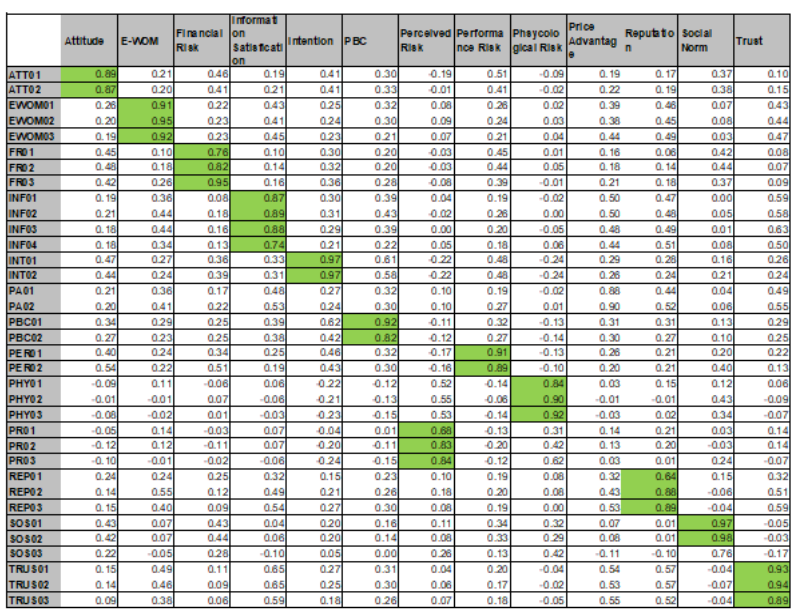

Figure 4. Cross Loading Result

\begin{tabular}{|l|r|r|r|r|}
\hline Path & Path Coefficient & T-Statistic $(a=0.05)$ & T Statistics & V Values \\
\hline Attitude $>$ Intention & 0.25 & 1.96 & 5.17 & 0 \\
\hline --WOM $>$ Trust & 0.17 & 1.96 & 2.82 & 0.01 \\
\hline Financial Risk $>$ Perceived Risk & -0.03 & 1.96 & 0.4 & 0.69 \\
\hline Information Satisfication $>>$ Intention & 0.03 & 1.96 & 0.53 & 0.6 \\
\hline PBC $>$ Intention & 0.46 & 1.96 & 9.42 & 0 \\
\hline Perceived Risk $>>$ Attitude & -0.13 & 1.96 & 1.81 & 0.07 \\
\hline Perceived Risk $>$ Intention & -0.15 & 1.96 & 3.47 & 0 \\
\hline Performance Risk $>$ Perceived Risk & -0.12 & 1.96 & 2.72 & 0.01 \\
\hline Phsycological Risk $>$ Perceived Risk & 0.59 & 1.96 & 13.15 & 0 \\
\hline Price Advantage $>$ Trust & 0.33 & 1.96 & 6.43 & 0 \\
\hline Reputation $>$ Trust & 0.34 & 1.96 & 4.91 & 0 \\
\hline Subjective Norm $>$ Intention & 0.04 & 1.96 & 0.88 & 0.38 \\
\hline Trust $>$ Attitude & 0.15 & 1.96 & 2.72 & 0.01 \\
\hline Trust $>>$ Intention & 0.07 & 1.96 & 1.25 & 0.21 \\
\hline Trust $>$ Perceived Risk & 0.11 & 1.96 & 1.9 & 0.06 \\
\hline
\end{tabular}

Figure 5. Path Coefficient result

latent variables meet the criteria, so that all latent variables are declared valid.

Composite Reliability is a measure of internal reliability consistency, unlike Cronbach's alpha which does not assume all indicators are the same. The value of composite reliability is declared reliable when it is more than 0.7 . Table 4 shows that all latent variables have composite reliability values above 0.7 , so that the latent variables are declared reliable.

Cronbach's Alpha is a measure of internal reliability consistency, which assumes all indicators are the same. The Cronbach's alpha value is declared reliable when it is more than 0.7. Table 5 shows that all latent variables have a Cronbach's alpha value above 0.7 , so that the latent variables are declared reliable.

$\mathrm{R}$-Square is a measure to explain the effect of exogenous latent variables on endogenous latent variables. Table 6 shows the R-Square value for the 4 dependent variables. The latent variable attitude shows a weak R-Square value. The latent variables intention, perceived risk, and trust show a moderate R-Square value. This shows that the latent variable intention can only be explained by $46.9 \%$ by other latent variables.

The path coefficient is used to estimate the path of the relationship in the structural model. The confidence level used in this research was $95 \%(\alpha=0.05)$ and the t-statistic

\begin{tabular}{|c|c|c|c|c|c|}
\hline \multicolumn{3}{|c|}{ Hypotesis } & \multirow{2}{*}{$\begin{array}{c}\text { Path } \\
\text { Coefficient }\end{array}$} & \multirow{2}{*}{ P Values } & \multirow{2}{*}{ Result } \\
\hline Code & Variabel & Effect & & & \\
\hline \begin{tabular}{|l|}
$\mathrm{H} 2$ \\
\end{tabular} & $\begin{array}{l}\text { Attitude } \\
\text { Buying Intention }\end{array}$ & Direct & 0.25 & 0 & Diterima \\
\hline H3 & $\begin{array}{l}\text { Subjective Norm - } \\
>\text { Buying Intention }\end{array}$ & Direct & 0.04 & 0.38 & Ditolak \\
\hline H4 & \begin{tabular}{|l|} 
Perceived \\
Behavior Control \\
$>$ Buying
\end{tabular} & Direct & 0.46 & 0 & Diterima \\
\hline H5 & \begin{tabular}{|l|} 
Information \\
Satisfication \\
Buying Intention
\end{tabular} & Direct & 0.03 & 0.6 & Ditolak \\
\hline H6 & \begin{tabular}{|l|l|} 
Trust $>$ Buying \\
Intention
\end{tabular} & Direct & 0.07 & 0.21 & Ditolak \\
\hline H7 & Trust $\rightarrow$ Attitude & Direct & 0.15 & 0.01 & Diterima \\
\hline H8a & $\begin{array}{|ll|}\text { Reputation } \quad \rightarrow \\
\text { Trust }\end{array}$ & Direct & 0.34 & 0 & Diterima \\
\hline $\mathrm{H} 8 \mathrm{~b}$ & $\begin{array}{l}\text { Price Advantage - } \\
>\text { Trust }\end{array}$ & Direct & 0.33 & 0 & Diterima \\
\hline H8c & E-WoM $\rightarrow$ Trust & Direct & 0.17 & 0.01 & Diterima \\
\hline H9 & \begin{tabular}{|l|} 
Perceived Risk $\rightarrow>$ \\
Intention
\end{tabular} & Direct & -0.13 & 0 & Diterima \\
\hline H10 & \begin{tabular}{|l|}
$\begin{array}{l}\text { Perceived Risk } \rightarrow> \\
\text { Attitude }\end{array}$ \\
\end{tabular} & Direct & -0.15 & 0.07 & Ditolak \\
\hline H11 & $\begin{array}{l}\text { Trust } \rightarrow \text { Perceived } \\
\text { Risk }\end{array}$ & Direct & 0.11 & 0.06 & Ditolak \\
\hline $\mathrm{H} 12 \mathrm{a}$ & $\begin{array}{|ll|}\text { Financial Risk } & \rightarrow \\
\text { Perceived Risk } & \end{array}$ & Direct & -0.03 & 0.69 & Ditolak \\
\hline $\mathrm{Hl} 2 \mathrm{~b}$ & $\begin{array}{l}\text { Performance } \\
\text { Risk -> Perceived } \\
\text { Risk } \\
\end{array}$ & Direct & -0.12 & 0.01 & Diterima \\
\hline $\mathrm{Hl} 2 \mathrm{c}$ & $\begin{array}{l}\text { Phsycological } \\
\text { Risk -> Perceived } \\
\text { Risk }\end{array}$ & Direct & 0.59 & 0 & Diterima \\
\hline
\end{tabular}

Figure 6. Hypotesis result

Table 6.

R-Square Result

\begin{tabular}{cc}
\hline \hline Variable & $\mathbf{R}$ \\
& Square \\
\hline Attitude & 0.036 \\
Intention & 0.469 \\
Perceived Risk & 0.384 \\
Trust & 0.483 \\
\hline \hline
\end{tabular}

used was 1.96. The positive value of the path coefficient shows that the latent variables that are related have a positive effect, and vice versa if the path coefficient is negative, the latent variables that are related have a negative effect. Figure 5 shows the results of the structural model path coefficient.

The main hypothesis in this study is to find out what factors influence the desire of buyers to buy goods on social media. Figure 5 shows the path coefficient leading to intention, namely from attitude, $\mathrm{PBC}$, and perceived risk with a p-value below 0.05 . So it can be concluded that there are several factors that influence the desire of buyers to buy goods on social media, which means that $\mathrm{H} 0$ is rejected and $\mathrm{H} 1$ is accepted so that the supporting hypothesis in this study can be tested and the results of testing the supporting hypothesis are shown in Figure 6.

Based on the results of hypothesis testing that has been done, 10 hypotheses have been accepted, namely $\mathrm{H} 1, \mathrm{H} 2, \mathrm{H} 4$, H5, H8a, H8b, H8c, H9, H12b, and H12c. Because the purpose of this study is to find out what factors influence the desire of buyers to buy products on social media, the accepted hypothesis must be checked first by seeing whether the 
hypothesis is on the path to the buying intention variable based on the existing conceptual model. in Figure 7.

Buying Intention is influenced by several factors, including Attitude, Perceived Behavior Control, and Perceived Risk. Then for the Attitude factor is influenced by Trust, and the Trust factor is influenced by Reputation, Price Advantage, and E-WoM. And finally, the Perceived Risk factor is influenced by Performance Risk and Psychological Risk.

\section{B. Result}

The results of the analysis show that reputation, price advantage, and E-WoM have a direct effect on the level of trust of buyers who wish to hang out on social media. This is indicated by the $\alpha$ value below 0.05 from each path leading to the trust variable and the R-Square value of 0.483 on the Trust variable where the variable reputation, price advantage and E-WoM as independent variables can explain $48.3 \%$ of the trust variable as dependent variable.

Reputation shows a direct influence on the level of trust of buyers who wish to purchase goods on social media. A seller who has a good reputation on social media will easily gain the trust of potential buyers because the seller is less likely to be dishonest with potential buyers.

Apart from reputation, price advantage also has a direct influence on the buyer's trust level. With the price given by the seller is not too expensive or too cheap, the buyer will feel confident in the seller. This is because buyers usually do a price survey before deciding to purchase a product. And finally, E-WoM or better known as word of mouth virtually also has a direct influence on the level of buyer's trust. EWoM here is in the form of positive or negative reviews about the product being sold. The more positive the reviews provided by previous buyers, the more trusting prospective buyers will want to make purchases on social media, and vice versa.

The results of the analysis show that performance risk and pyschological risk have an effect on buyers' perceived risk, this is indicated by an $\alpha$ value below 0.05 . Meanwhile, financial risk has an $\alpha$ value above 0.05 , which means that financial risk does not have a direct effect on buyers' perceived risk. The R-Square value of 0.384 in the perceived risk variable indicates that the performance risk and psychological risk variables are able to explain $38.4 \%$ of the perceived risk variables.

Performance Risk occurs when the product that the buyer wants to buy does not match the buyer's request, such as error in size, motif, there are blisters on the product received and others. This makes potential buyers think again about purchasing goods to avoid these risks. Psychological risk occurs when someone gets pressure from the social environment as a result of having purchased a product. This pressure can be in the form of insults, ridicule, etc., so that the buyer will think again about the consequences of this risk.

The results of the analysis show that trust does not have a direct effect on the risk perception of potential buyers who wish to buy products on social media. This is indicated by the $\alpha$ value above 0.05 . The level of confidence of a prospective buyer has no effect on the perceived risk that will be accepted when making a purchase, because even though the level of buyer's confidence is high, it is possible that the seller is not honest with the buyer. So that the buyer will accept the risk when buying products from the seller.

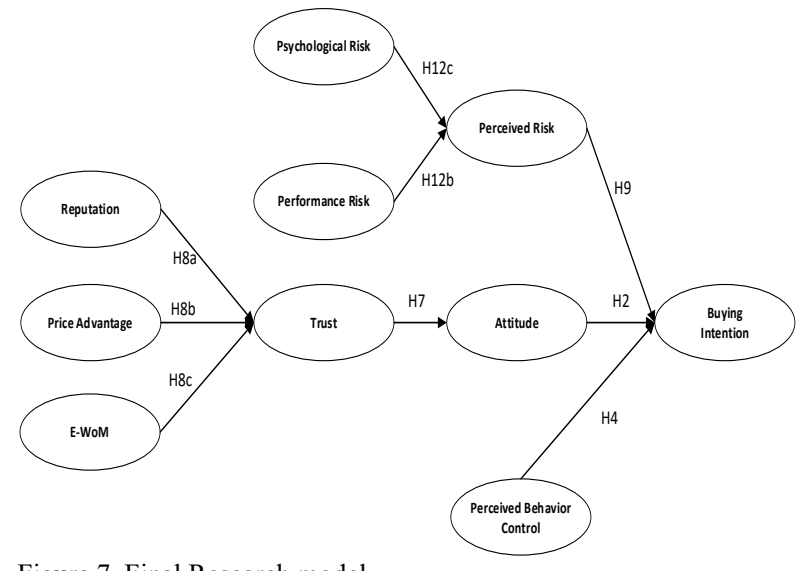

Figure 7. Final Research model

The results of the analysis show that the level of trust affects the attitudes of buyers who have the desire to purchase products on social media. This is indicated by the value of $\alpha$ owned by the trust variable below 0.05 . Meanwhile, the perceived risk has a value of $\alpha$ above 0.05 , indicating that the risk perception does not affect the buyer's attitude. The RSquare value of 0.036 on the Attitude variable indicates that the Trust variable only explains $3 \%$ of the Attitude variable. This indicates that there are other variables that influence the attitude of buyers who want to purchase products on social media.

The level of trust of potential buyers who wish to make purchases on social media affects the attitudes of these prospective buyers. The higher the level of trust a prospective buyer has, the more positive the attitude of the buyer who wants to purchase products on social media.

The results showed that perceived risk, attitude and perceived behavior control had a direct effect on buyers' desire to buy products on social media. This is indicated by the value of $\alpha$ in each variable with a value of more than 0.05 . Meanwhile, trust and subjective norm have a value of $\alpha$ above 0.05 , so that trust and subjective norm have no direct effect on buyers' desires. The R-Square value of 0.469 on the intention variable shows that the variables of perceived risk, attitude and perceived behavior control explain $46.9 \%$ of the intention variable.

The better the risk perception the buyer has, the higher the desire of the buyer to purchase the product. This happens because buyers feel the risks they have when purchasing products on social media are small. Apart from the perception of risk, the attitude of the buyer also affects the desire of the buyer to purchase products on social media. The more positive the buyer's attitude, the higher the desire of the buyer to buy the product. The behavioral control perception factor shows that buyers who wish to make product purchases have the ability to make these purchases.

Of the 9 factors that are stated to have an influence on the desire of buyers to purchase products on social media, namely Attitude, Perceived Risk, Perceived Behavior Control, Reputation, Price Advantage, E-WoM, Trust, Performance Risk, Psychological Risk. From these 9 factors, 5 recommendations were selected which have implications for the XYZ store management, namely Attitude, Perceived Behavior Control, E-WoM, Price Advantage, and Perceived Risk, where the selection of these recommendations is based on the conditions of the XYZ store. 
For the Attitude factor, the recommendation that can be given is that XYZ Store should be able to motivate prospective buyers who wish to purchase products on social media. This is done by providing friendly and polite service when prospective buyers ask about the products being sold, so that buyers have a positive attitude towards XYZ Stores and are willing to make purchases.

Every time you make a purchase on social media, there will be risks that will harm the buyer, so that the buyer does not want to make a purchase. For the Perceived Risk factor, the recommendation that can be given is that the $\mathrm{XYZ}$ Store should be able to minimize the risk that will be caused by the product purchase process, such as damage to the product that is sent can be resolved by periodically checking the products being sold, delays in product delivery that can be overcome by choosing a service provider trusted package delivery, product errors that can be resolved by providing a catalog regarding the specifications of the product being sold, and fraud that can be overcome by providing clear contacts and payment processes.

For the E-WoM factor, the recommendation that can be given is that XYZ Stores should display advertisements containing testimonials / reviews from previous buyers. In addition, XYZ Store can also endorse artists on social media to provide reviews of products being sold, so that it can attract a lot of attention from potential buyers and the level of buyer's trust in buying goods on social media.

Price is a parameter seen by potential buyers who wish to purchase a product. The higher the price given by the seller, the less the buyer is willing to make a purchase. If the lower the price, the buyer will want to make a purchase. For the Price Advantage factor, the recommendation that can be given is that XYZ Store should put a price on products that are competitive with market prices, but not too low because buyers will be suspicious of the products sold by XYZ Stores. In addition to installing product prices below market prices, XYZ Stores can also provide promos or discounts to products sold on social media, so buyers want to buy these products.
Prospective buyers who feel confident and desire to make purchases on social media are usually more likely to make purchases on social media. For the Perceived Behavior Control factor, the recommendation that can be given is that XYZ Store can provide a tutorial on how to make transactions at XYZ Stores on social media so that it can increase buyers' desire to shop at XYZ Stores on social media.

\section{REFERENCES}

[1] APJII, "Penetrasi \& Perilaku Pengguna Internet Indonesia,” 2017.

[2] APJII, "Profil Penggunaan Internet Indonesia," 2014.

[3] APJII, "Survei Penetrasi Internet," 2018.

[4] K. Kotler, Marketing Management 15, Pearson Education, 2016.

[5] A. Humaira and H. Hudrasyah, "Factors influencing the intention to purchase and actual," JOURNAL OF BUSINESS AND MANAGEMENT, vol. 5, no. 4, pp. 581-596, 2016.

[6] A. M. Primabudi, "Analisa Faktor-Faktor Yang Mempengaruhi Keputusan Pembelian Pada Toko Online. Studi Kasus: Penjualan Game Secara Online," 2017.

[7] I. Ajzen, "The theory of planned behavior," ORGANIZATIONAL BEHAVIOR AND HUMAN DECISION PROCESSES, vol. 50, no. 2, pp. 179-211, 1991

[8] C. H. Park, Y. G. Kim, "Identifying key factors affecting consumer purchase behavior in an online shopping context," International Journal of Retail \& Distribution Management, vol. 31, no. 1, pp. 16-29, 2003.

[9] I. B. Yahia, N. Al-Neama, L. Kerbache, "Investigating the drivers for social commerce in social media platforms: importance of trust, social support and the platform perceived usage," Journal of Retailing and Consumer Services, vol. 41, p. 11-19, 2018.

[10] F. D. Virgilio, G. Antonelli, "Consumer Behavior, Trust, and Electronic Word-of-Mouth Communication,” IGI Global, 2018, pp. 58-80.

[11] L. H. Kim , D. J. Kim, and J. K. Leong, "The effect of perceived risk on purchase intention," Journal of Hospitality \& Leisure Marketing, vol. 13, no. 2, pp. 33 - 53, 2008.

| [12] S. L. Jarvenpaa, N. Tractinsky, and M. Vitale, "Consumer trust in an internet store," Information Technology and Management, vol. 1, no. 1, pp. 45-71, 2000.

| [13] J. Yang, R. Sarathy, and J. K. Lee, "The effect of product review balance and volume on online shoppers' risk perception and purchase intention," Decision Support Systems, vol. 89, pp. 66$76,2016$. 